\title{
Dairy goat husbandry amongst the household agriculture: herd and economic indexes from a case study in Rio de Janeiro, Brazil
}

\author{
Ricardo Augusto Mendonça Vieira ${ }^{1}$, Artur José Cabral ${ }^{2}$, Paulo Marcelo de Souza ${ }^{3}$, Alberto Magno \\ Fernandes ${ }^{1}$, Douglas Sampaio Henrique ${ }^{4}$, Gabriela Soares Carvalho Pamplona Corte Real ${ }^{2}$ \\ 1 Universidade Estadual do Norte Fluminense Darcy Ribeiro - CCTA - LZNA. \\ 2 Pós-Graduação em Ciência Animal - Universidade Estadual do Norte Fluminense Darcy Ribeiro - CCTA - LZNA. \\ 3 Universidade Estadual do Norte Fluminense Darcy Ribeiro - CCTA - LEAG \\ 4 Pós-Graduação em Zootecnia - Universidade Federal de Viçosa - CCA - DZO.
}

ABSTRACT- Two dairy goat systems conducted according to the household model were evaluated in terms of income generation. An enterprise budget analysis was performed using data collected from August, 2004, to July, 2005. Farms named A and B were smallholdings and raised Saanem goats intensively. Herd indexes, incomes, taxes, fuel, energy, concentrates, opportunity costs and interest in capital were computed. Net present value and internal rate of return were estimated to appreciate the business appeal in terms of income generation. Herd indexes were mostly affected by management decisions interfering on the amounts and time-trends related to milk production. Seasonal variation was reduced at unit B due to heat induction, a decision not shared by farmer A. The daily body weight gain of doelings after weaning ( 89 and $76 \mathrm{~g} / \mathrm{d}$ for A and B) was low if compared to current recommendations. Average records of lactation (441 and $606 \mathrm{~L} / \mathrm{doe})$ and fertility $(86.95 \%$ and $85.71 \%$ ) were amongst the literature range. Daily tasks related to unit B consumed 5 hours and 55 minutes for an average milk production of $40.9 \mathrm{~L} / \mathrm{d}$, whereas 8 hours and 16 minutes on average were daily spent at unit $\mathrm{A}$ in order to produce $32.2 \mathrm{~L} / \mathrm{d}$. Unit B presented a total production cost ( $\mathrm{R} \$ 0.79548 / \mathrm{L})$ lower than unit A ( $\mathrm{R} \$ 1.50239 / \mathrm{L})$, but operated profitably. Unit A presented a positive gross margin ( $\$$ \$ $0.284 / \mathrm{L}$ ), but operated unprofitably. The income generated on B was equivalent to a monthly salary of R $\$ 732.96$ (US\$278.52), a competitive income compared to the Brazilian minimum wage of R $\$ 300.00$ (US\$ 114.00) paid monthly. These results corroborate the hypothesis that the dairy goat husbandry fits adequately to the household production model and generates income competitively.

Key Words: agribusiness, enterprise budget analysis, family labour

\section{A caprinocultura leiteira na agricultura familiar: índices zootécnicos e econômicos de um estudo de caso no estado do Rio de Janeiro, Brasil}

RESUMO - Dois sistemas de produção de caprinos leiteiros praticados de acordo com o modelo familiar foram avaliados quanto à geração de renda. Um teste para verificação de viabilidade econômica do empreendimento foi executado utilizando-se dados coletados de agosto de 2004 a julho de 2005. As fazendas, denominadas A e B, eram pequenas propriedades produtoras de cabras Saanem em sistema intensivo. Índices de rebanho, rendas, impostos, combustível, energia, concentrado, custos de oportunidade e capital de interesse foram computados para estimação da renda líquida e da taxa de retorno do capital para avaliação do quanto o negócio pode ser atraente em geração de renda. Os índices de rebanho foram afetados significativamente pelas decisões tomadas pelos administradores e interferiram sobre as quantidades e tendências relacionadas à produção de leite. Na unidade $\mathrm{B}$, a variação sazonal reduziu com a indução de cio, uma prática não realizada na unidade A. O ganho de peso diário das cabritas após a desmama ( 89 e $76 \mathrm{~g} /$ dia para A e B) foi baixo em comparação às recomendações atuais. As médias dos registros de lactação (441 e 606 L/cabra) e fertilidade ( 86,95 e 85,71\%) estiveram nos limites preconizados na literatura. Tarefas diárias na unidade B consumiam 5 horas e 55 minutos para produção média de leite de 40,9 L/dia, enquanto na unidade A correspondiama 8 horas e 16 minutos diários para produção média de 32,2 L/dia. A unidade B apresentou custo total de produção (R $\$ 0,79548 / \mathrm{L}$ ) menor que o da unidade A ( $\mathrm{R} \$ 1,50239 / \mathrm{L})$, mas operava de forma lucrativa. A unidade A apresentou margem bruta positiva ( $\mathrm{R} \$ 0,284 / \mathrm{L})$, mas não operava de forma lucrativa. A renda gerada em B era equivalente a um salário mensal de R \$ 732,96 (US\$ 278,52), renda competitiva se comparada ao salário mínimo brasileiro, de R \$300,00 (US\$ 114,00) por mês. Estes resultados corroboram a hipótese de que a produção de caprinos leiteiros serve adequadamente ao modelo de produção familiar e gera renda competitiva.

Palavras-chave: agronegócio, trabalho familiar, viabilidade econômica do empreendimento

Este artigo foi recebido em 19/11/2007 e aprovado em 28/7/2008.

Correspondências devem ser enviadas para: ricardo.vieira@pesquisador.cnpq.br 


\section{Introduction}

The average area of rural properties in the State of Rio de Janeiro (Brazil) reduced considerably from 120 to 45 ha between the 20's and the 90's (IBGE, 1976; CIDE, 1998). Such size reduction compromises the succession of household productive units because land accessibility is the main reason for family agribusiness extinction (Abramovay, 2000; Zaibet et al., 2004).

Modern household agriculture can be characterised by partial commercialization of products and additional income obtained with non-farm activities (Zaibet et al., 2004). But if the family does not hold all factors that ensure a satisfactory income, a disinterest about traditional activities, particularly by young farmers, grows (Abramovay, 2000; Silvestro et al., 2001; Zaibet et al., 2004). Therefore, when an economical analysis of household enterprises is in course with the objective to characterise the business appeal, the family labour opportunity cost should be considered (MorandFehr and Boyazoglu, 1999; Abramovay, 2000; Morand-Fehr et al., 2004).

The enterprise budget analysis is an important tool for evaluating such characteristics and demands a detailed survey about the available farm production factors as well as how they are used. However, the target activity developed at a determined region should be adequately represented, and henceforth, farms that gather attributes concerning technical and economical efficiency should be chosen as a reference to the farm technological profile, the farmer goals, and reflect the technological and productive levels tangible for the majority of shepherds (Gomes et al., 1995).

In Brazil, specifically on its south-eastern region, the goat milk production is intensive and a dairy belt has been consolidated between the States of Rio de Janeiro and Minas Gerais. Dairy breeds of European origin are raised and the main product of the activity is milk, mainly traded in its fluid form (Silva, 1998; Cordeiro, 2001). The main commercial goat milk collection and dairy products market is in the State of Rio de Janeiro. At the county of Porciúncula, north-western region of the State, the dairy goat activity is performed intensively by household farmers, whose business became feasible since a regular milk collection by the industry had begun ${ }^{1}$. The present work was motivated by the hypothesis that the dairy goat activity in the household model would assure appropriate income for rural families. Therefore, an enterprise budget analysis was applied to evaluate the performance of this activity in generating income for its owner family on the rural environment.

\section{Material and Methods}

Field data collection occurred from August 2004 to July 2005 in two small properties with household production profiles in the county of Porciúncula, State of Rio de Janeiro, Brazil. These farms were chosen because owner families hold all necessary production factors; they were responsible for the decision-making process and performed daily tasks associated to their enterprises. A decisive point for their choice was the fact that both were main suppliers of goat milk to the Associação dos Caprinocultores do Noroeste Fluminense ${ }^{2}$ (North-western Fluminense Goat Producers Association), settled in Porciúncula, and because they make use of production technologies tangible to other affiliates. The association was formed by 26 affiliates and sold received milk to a dairy industry established at the city of Nova Friburgo, State of Rio de Janeiro.

Porciúncula $\left(20^{\circ} 57^{\prime} \mathrm{S}, 42^{\circ} 2^{\prime} \mathrm{W}\right)$ has a population of 16,093 inhabitants and a geographic area of $302 \mathrm{~km}^{2}$, with ahuman development index of 0.73 (PNUD, 2006; IBGE, 2006). The municipal seat is at $184 \mathrm{~m}$ of altitude, but altitudes higher than $600 \mathrm{~m}$ are recorded. The topography is irregular and the valley crossed by Carangola River and its tributaries has a predominant Gleysol type whereas Ferralsol, Luvisol, Lixisol and Acrisol prevail on hills and highlands. According to Köppen standards, Aw climate predominates at low altitude areas, whereas Cwa climate encompasses highlands near the boundaries with the States of Minas Gerais and Espírito Santo. The municipal seat is $380 \mathrm{~km}$ far from the city of Rio de Janeiro, the state capital.

The production units were named $\mathrm{A}$ and $\mathrm{B}$, their farmhouses were $250 \mathrm{~m}$ far from each other and were at 237 and $225 \mathrm{~m}$ from the sea level. The unit B farmhouse was closer to the county seat and $3.5 \mathrm{~km}$ far from the milk receiving station of the association. The topography of both units is irregular and there were no plain areas that would justify conventional mechanization. Gleysol prevailed on few existing valley areas and production units shared a little watercourse. Both farmers raised dairy goats intensively on wooden stilted-type barns with slatted floors.

\footnotetext{
${ }^{1}$ Cordeiro, "personal communication”, 2005, Celles Cordeiro Alimentos Ltda, Rio de Janeiro, Brazil.

${ }^{2}$ The word "Fluminense" derives from the Latin flumen, which means river - "rio" in Portuguese. It is an adjective related to the State of Rio de Janeiro.
} 
Farm A had 17 ha, but dairy goats occupied only a half ha. Dairy goats were exclusively for commercial purposes; other stock and crops were produced for home consumption and sporadically sold at the local market. Family was composed by husband (58), wife (40), one single son (18) and wife's father (66) and mother (61). The whole family lived in the city, where the owner couple was civil servants. The son was a student and the wife's parents were retired. Therefore, this family did not depend on income generated by their production unit. A permanent worker helped the wife's father in performing daily tasks. The owner couple and their son were responsible for the farm management and worked sporadically at the farm on weekends and holidays. The herd was formed by 23 lactating does, 15 nine-month doelings, five twelve-month doelings of and two bucks. Animals were fed with concentrate bought locally and napier grass (Pennisetum purpureum, Schumacher cv. Napier), that was cultivated on 0.3 ha to provide fresh chopped forage ad libitum. Goat manure was used for fertilizing the forage field. According to the owner, this area had never received conventional fertilizers.

Production unit B had 7.2 ha available, but only 0.21 ha were used for the dairy goat activity. Dairy cattle production occupied the rest of the land as well as the remaining time of the family labour force. This family lived at the farm and worked on both activities, because products (goat milk, cow milk and animals) were of commercial interest. Necessary income for survival and other needs of the family such as clothing, education, leisure and savings, depended exclusively on their livestock activities. The husband (40) was responsible for harvesting green angola grass (Urochloa mutica (Forssk.) T.Q. Nguyen) cultivated on 0.17 ha. That area supplied forage to the goat herd at one year-round basis and, according to the owner, never received chemical fertilizers, only goat manure. The eldest son (17) and the youngest son (13) helped him with this task, as well as with regular removing of goat manure under the slatted-floored barn to the forage production area. The wife (40) was responsible for feeding chopped forage and concentrate (bought locally) to the herd, for milking of does and preparing milk to be transported to the association. The youngest son helped her with daily tasks. The wife had double journey, by taking care of domestic work as well. The husband is an agricultural technician and was responsible for business management. Herd was formed by 27 does, 15 lactating ones, nine nine-month doelings and one buck.

Technical indices of both herds were estimated from data provided by farm owners, and when necessary information was not available, direct measurements were performed. Milk selling was monthly recorded from milk receipts issued by the association (at units A and B) and from daily records of milk sold locally (at unit B, only). Selling, acquisition and deaths of animals were registered and both herds were monthly weighed. Males born at both farms were discarded on its majority. Does were handmilked on both farms.

The business performance of each production unit was evaluated by means of the enterprise budget analysis, which allowed discriminating revenues, expenses, production factors and amounts produced and evaluation of each unit based on technical efficiency coefficients. Field data were tabulated on a spreadsheet program (Microsoft ${ }^{\circledR}$ Excel 97) to accomplish the financial and economical performance estimates of both farms. Thus, the total receipts (TR, R\$/year) obtained during the surveyed period was calculated as:

$\mathrm{TR}=\mathrm{MP} \times \mathrm{MQ}+\mathrm{Pa} \times \mathrm{Qa}+\Delta \mathrm{CS}$

where MP is the average milk price $(\mathrm{R} \$ / \mathrm{L}), \mathrm{MQ}$ is the quantity of milk sold (L/year), $\mathrm{Pa}$ is the mean price of live animals at local market $(\mathrm{R} \$ / \mathrm{kg})$ and $\mathrm{Qa}$ is the quantity of animals sold (kg/year). The term $\Delta \mathrm{CS}$ corresponds to the yearly capital stock variation,

$\Delta \mathrm{CS}=\mathrm{Pa} \times(\mathrm{FHM}-\mathrm{IHM})-\mathrm{TAV}$

in which IHM and FHM correspond to the initial and final herd masses $(\mathrm{kg})$ determined during the surveyed period, and TAV is the total expenses with animal acquisitions (R\$/year).

Direct expenses done by farmers were computed by estimating the effective operational costs (EOC) of both units: concentrates, wages, medicines, fuel, energy, buildings and equipment maintenance, milk transport, taxes, social security, and other uneven expenses. Total operational costs (TOC) were estimated by adding the family labour opportunity cost to the respective EOC, either for daily tasks and management, as well as depreciation of production factors: building, equipment and service animals. The value of the management labour was assumed to be $25 \%$ of three Brazilian minimum wages with all legal taxes and rights included. Production animals were not depreciated because it was assumed that does at the end of productive life would be replaced by doelings, thus maintaining the average age of does stable. Depreciation was based on initial and residual values, and on useful life of production factors. Depreciation was not applied to land.

Total cost of the activity (TC) was estimated by adding the interest on circulating and fixed capital to TOC, including the land use opportunity cost. For these 
calculations, land renting as pasture for cattle ( $\mathrm{R} \$ / \mathrm{ha} / \mathrm{year})$ and an interest rate of $6 \% / y e a r$ were assumed. The costs of milk production in both enterprises were estimated by discounting revenues provided by selling animals and $\Delta C S$ (Eq.2) from the TC. The result was divided by the amount of milk produced yearly to estimate the unitary goat milk production costs $(\mathrm{R} \$ / \mathrm{L})$ for both farms.

Gross margins were estimated by the difference between TR (Eq.1) and EOC. Profits were estimated by the difference between TR and TC. The rates of return of the invested capital (r) were estimated by the following expression:

$\mathrm{r}(\% /$ year $)=(\mathrm{TR}-\mathrm{TC}) \times 100 / \mathrm{I}$

where I corresponds to investments done on farms A and B. The land cost was optionally included by computing its average local value at that time ( $\mathrm{R} \$ 3,443.52 / \mathrm{ha})$.

Technical efficiency coefficients were estimated for all production factors, including family labour and wages. Coefficients were obtained by dividing the amount of each factor used by the volume of milk sold. Whenever necessary, a $t$-test (error $\alpha=0.10$ ) was applied to detect possible differences among sampled variables to help to understand how management decisions and systems peculiarities affected the economical performance.

The economical feasibility was evaluated after estimating the net present value (NPV) and the internal rate of return (irr), only in case of profitability. Therefore, yearly cash flows $\left(\mathrm{C}_{\mathrm{k}}\right)$ registered during the studied period $(\mathrm{k}=0,1)$ were projected four years ahead $(\mathrm{k}=2,3,4,5)$. By applying an interest rate (i) of 6\%/year, the NPV was estimated as:

$\mathrm{NPV}=\sum_{\mathrm{k}} \mathrm{C}_{\mathrm{k}} /(1+\mathrm{i})^{\mathrm{k}}, \forall \mathrm{k}=0,1,2, \ldots, 5$ years,

where $\mathrm{C}_{0}$ is the initial investments performed (I, Eq.3), and the current Brazilian policy concerning prices stability was assumed. NPV and irr were estimated based on algorithms implemented on Microsoft ${ }^{\circledR}$ Excel 97. Additionally, to assess the business strength, asensitivity test was applied over feasibility indicators (NPL and irr) based on a pessimist scene simulation, for which a cumulative $7 \% / y e a r$ increase were imputed over the production costs while revenues were kept unaltered on cash flows.

\section{Results and Discussion}

Porciúncula is located at a humid tropical region with oceanic influence. The daily average temperature and relative humidity were $23.1^{\circ} \mathrm{C}$ and $83 \%$, and a $1,615 \mathrm{~mm}$ of rainfall was recorded during $2004 / 2005$. Only $6.4 \%$ of the estimated rainfall occurred from May to September, when average maximum and minimum temperatures were 28.4 and $15.4^{\circ} \mathrm{C}$. From October to April, 93.6\% of rainfall and average maximum and minimum temperatures at 30.9 and $20.3^{\circ} \mathrm{C}$ were recorded. Drought periods at high summer with 15 to 25 days in length in January and February frequently occur, as confirmed by January rainfall recordings of only $7.4 \%$ of the total rainfall observed.

The herds under study were composed of animals of Saanem breed pattern, the same breed of herds raised by the other goat farmers at Porciúncula and other counties of the state. The existence of these herds corroborates the hypothesis about the adaptability of European breeds to different environmental conditions, including good adaptation to the tropical humid climate. Withintensification of productive processes, these animals became less dependent on climate, geophysical and social-economic conditions, favouring the breeding of dairy animals in tropical regions (Boyazoglu\& Morand-Fehr, 1987; Osuji, 1987; Knights \& Garcia, 1997). At the south-eastern region of Brazil, these breeds are somewhat raised easily, allowing the formation of specialized dairy belts (Cordeiro, 2001). The county farmers association became the greatest goat milk supplier to the main goat milk industry settled at the State at the end of 2005, by using these animals and contributing with $126,405 \mathrm{~L}$. The combined milk yields of farm units A and B contributed with $20 \%$ of total milk received by the association in that year ${ }^{3}$.

Despite the sampling limitations, some differences between technical indexes of the studied herds occurred because of management decisions taken by each family (Table 1). The shorter kidding interval $(\mathrm{P}=0.0753)$ of farm unit B occurred as a consequence of heat induction in October 2004, thus reducing the service period $(\mathrm{P}=0.0645)$ and anticipating part of does mating (nine does) that would be naturally mated between February and July. The owner of farm unit B used the light program technology associated to the buck effect to avoid shortage of monthly milk yield from February until July, sparing excess production in season (Figure 1b). The success of these combined technologies occurred due to simplicity: 16 to 18 hours of light per day was accomplished by using $150 \mathrm{~W}$ bulb lamps to stimulate females and bucks, and the use of a SRD (without definite race) buck able to mate independently of season enhanced the light program effect because of its odour and presence. That procedure was applied because the industry had signalised to implement a differentiated price policy at the 2005/2006-season output. This decision 
Table 1 - Technical herd indexes obtained from both farm units ${ }^{1}$

\begin{tabular}{|c|c|c|}
\hline Herd index & $\begin{array}{l}\text { Farm A } \\
\bar{x}( \pm s ; n)^{2}\end{array}$ & $\begin{array}{l}\text { Farm B } \\
\bar{x}( \pm s ; n)^{2}\end{array}$ \\
\hline Kidding interval (months) & $12.5 \mathrm{a}(1.9 ; 8)$ & $10.5 \mathrm{~b}(1.7 ; 5)$ \\
\hline Fertility $(\%)^{3}$ & 86.95 & 85.71 \\
\hline Litter size (kids/birth) & $1.8 \mathrm{a}(0.7 ; 24)$ & $1.5 \mathrm{a}(0.7 ; 33)$ \\
\hline$\%$ females to total kids ${ }^{3}$ & 38.64 & 47.00 \\
\hline Kid weight at birth $(\mathrm{kg})$ & $3.2 b(0.6 ; 18)$ & $3.7 \mathrm{a}(0.8 ; 21)$ \\
\hline Age at weaning (days) ${ }^{3}$ & 60 & 60 \\
\hline Weight at weaning $(\mathrm{kg})$ & $13.1 \mathrm{a}(4.1 ; 7)$ & $13.4 \mathrm{a}(2.2 ; 6)$ \\
\hline Age at first mating (months) & $9.1 \mathrm{~b}(0.6 ; 5)$ & $15.3 \mathrm{a}(1.6 ; 6)$ \\
\hline Weight at first mating $(\mathrm{kg})$ & $27.5 \mathrm{~b}(4.0 ; 5)$ & $38.7 \mathrm{a}(8.0 ; 6)$ \\
\hline Service period (days) & $231 \mathrm{a}(54 ; 8)$ & $166 \mathrm{~b}(56 ; 5)$ \\
\hline Age at first kidding (months) & $14.1 \mathrm{~b}(0.6 ; 5)$ & $20.5 \mathrm{a}(1.6 ; 6)$ \\
\hline Weight at first kidding $(\mathrm{kg})$ & $37.7 b(4.5 ; 5)$ & $49.8 \mathrm{a}(6.8 ; 6)$ \\
\hline Lactating period (days) & $306 a(43 ; 8)$ & $268 \mathrm{a}(45 ; 5)$ \\
\hline Total milk production per animal (L/lactation) ${ }^{3}$ & 441 & 606 \\
\hline Average milk production per animal $(\mathrm{L} / \mathrm{doe} / \mathrm{d})^{3}$ & 1.53 & 2.18 \\
\hline Total milk production per herd (L/year) $)^{3}$ & 11,743 & 14,926 \\
\hline Mortality $(\%)^{3}$ & 8.70 & 13.88 \\
\hline
\end{tabular}

${ }^{1}$ Means followed by different superscripts at the same row differ $(\mathrm{P}<0.10)$.

${ }^{2}$ Corresponds to estimated sample mean and $\mathrm{s}$ and $\mathrm{n}$ within parentheses to sample standard deviation and size.

${ }^{3}$ Values were derived from total herd counts in farms A and B.

was not shared by unit A owner family, which maintained a seasonal production pattern (Figure 1a). As a corollary, milk volume, milk yield distribution and percentage of lactating does to total herd presented different trends between the units (Table 1, Figure 1). The reproductive program avoided a seasonal milk production trend at unit B: $42.7 \%$ of its annual milk yield occurred between February and July 2005 (off season output) and 57.3\% occurred from August 2004 to January 2005 (season). Meanwhile, $75.8 \%$ of the milk production at unit A occurred during season. Seasonal reproduction compromises the profitability ifmilk yield in season exceeds $80 \%$ of yearly milk production (Castro, 1987). Other variables were also affected by intervention in B herd reproduction such as doelings age at first mating that was delayed deliberately $(* * \mathrm{P}<0.01)$, which resulted in higher body weights at first mating $(\mathrm{P}=0.0149)$, at first kidding $(* * \mathrm{P}<0.01)$ and higher age at first kidding $(* * \mathrm{P}<0.01)$. Although the lactations lengths did not differbetween farms $(P=0.1610)$ because of sampling limitations and lack of information about kidding dates, their estimates of the shortening effect of the unit $B$ reproductive program on lactation length at that time. Nevertheless, after enduring two mating seasons, it is reasonable to expect that lactation would last 10 months as observed for unit $\mathrm{A}$, whether lactation results from an induced conception or not (Table 1).

The fertilities of both herds were practically the same (Table 1), but it could be improved, since the average fertility values of dairy goats raised by household farmers in developing Countries has achieved $96 \%$ historically (Castro, 1987). Other reproductive indexes were also affected by management of each business (Table 1). The higher birth weight at unit $\mathrm{B}(\mathrm{P}=0.0308)$ may haveoccurred as a result of possible differences concerning daily energy and protein intake during gestation, since diet management did not seem to interfere in litter size $(\mathrm{P}=0.1195)$. The nutritional management affects the number and the weight of kids at birth, and daily energy requirements for single gestations are proportionally higher than those for twins or triplets (AFRC, 1997; Sahlu et al., 2004). This means lighter kids from multiple births and heavier kids at birth from wellnourished does throughout gestation.

Doelings should be first mated at $60 \%$ of mature weight (AFRC, 1997), implicating an average gain of $150 \mathrm{~g} / \mathrm{d}$ that favours mating at seven months and kidding at 12 months old. If the observed average kid weight at birth (Table 1) and the recommended daily gain of $138 \mathrm{~g} / \mathrm{d}$ (Luo et al., 2004) are considered, doelings weights at seven months of 32.2 and $32.7 \mathrm{~kg}$ might be expected for farms A and B, respectively. However, the doelings growth was compromised, since daily average gains of only 89 and $76 \mathrm{~g} / \mathrm{d}$ on average could be calculated from Table 1. Pre-weaning lasted the same and weaning weights did not differ between units $(\mathrm{P}=0.9050)$, and average daily gains of 165 and $160 \mathrm{~g} / \mathrm{d}$ were respectively observed during this phase. These rates were greater than $139 \mathrm{~g} / \mathrm{d}$ as reported by Luo et al. (2004) for the suckling phase and indicate that the doelings performance was restricted after weaning. 


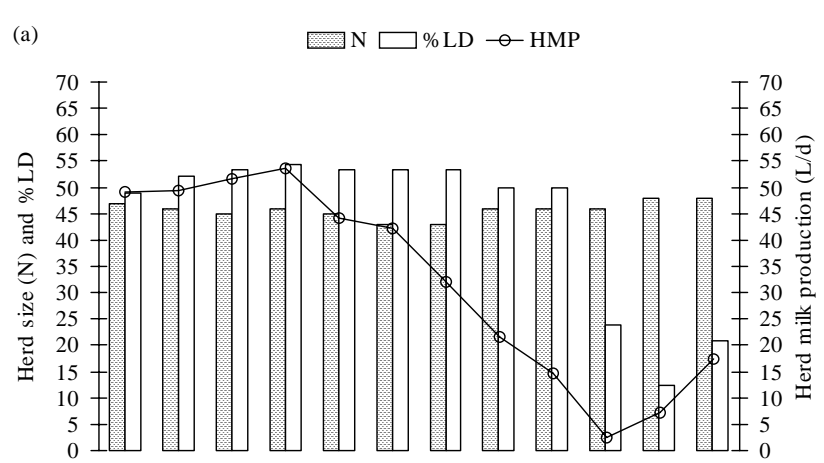

(b)

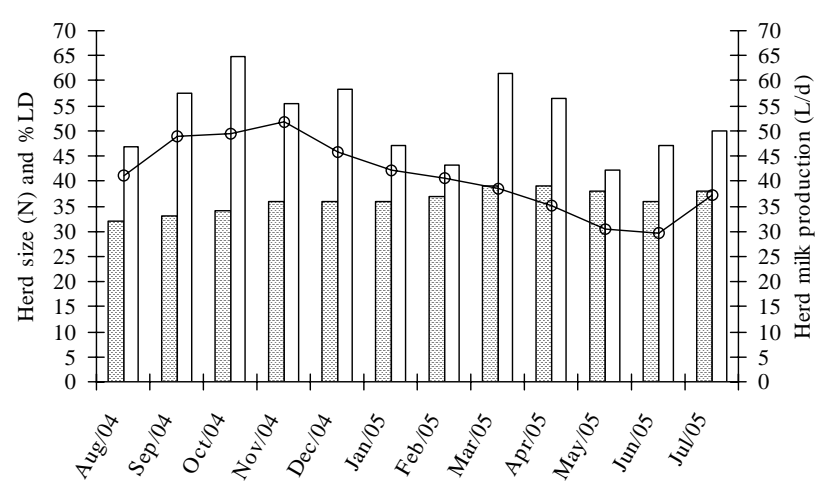

Figure 1 - Monthly distribution of herd size (N), percentage of lactating does to herd size (\%LD), and average daily herd milk production (HMP, L/d) for farms A (a) and $\mathrm{B}$ (b) during the studied period.
The average lactation milk yields registered (Table 1) were amongst the range observed in the literature, in which production recordings between 420 and 1,090 L/lactation can be found for European breeds raised at both temperate or tropical conditions (AFRC, 1997; Knights \& Garcia, 1997; Guimarães, 2004). Productivity between 1.9 and $4.4 \mathrm{~kg} / \mathrm{d}$ can be reached by herds of this breed pattern raised in the tropics, with lactations lasting 250 to 350 days in length (AFRC, 1997; Knights and Garcia, 1997; Nsahlai et al., 2004).

Labour efficiency differed in some aspects between goat farms (Table 2). Forage chopping $(* * \mathrm{P}<0.01)$, feeding of animals $(* * \mathrm{P}<0.01)$ and forage harvesting $(* * \mathrm{P}<0.01)$ were accomplished more efficiently in farm unit B. Milk transportation was more efficient in farm unit $\mathrm{A}(\mathrm{P}=0.0247)$ due to utilization of an automobile, whereas in farm unit B, a horse drawn-cart was used. Labour technical coefficients related to milking of does did not differ $(\mathrm{P}=0.5649)$, as well as milk preparing to be transported to the association $(P=0.2744)$ and cleaning manure under barns $(P=0.9738)$.

Daily tasks related to dairy goat breeding in farm unit A consumed, on average, eight hours and 16 minutes of daily work. At farm B, the owner and the eldest son carried out the hardest tasks, such as forage harvesting and processing and removing goat manure; time spent at these tasks occupied $44 \%$ of the family working time dedicated to the activity. The wife and the youngest son used $56 \%$ of the family time spent with other daily tasks related to the

Table 2 - Technical coefficients of labour efficiency ${ }^{1}$ related to daily tasks in both households ${ }^{2}$

\begin{tabular}{|c|c|c|}
\hline Efficiency coefficient & $\begin{array}{l}\text { Farm A } \\
\bar{x}( \pm s ; n)^{3}\end{array}$ & $\begin{array}{l}\text { Farm B } \\
\bar{x}( \pm s ; n)^{3}\end{array}$ \\
\hline Milking of does ${ }^{4}$ & $7,123.0 \mathrm{a}(3,529.7 ; 22)$ & $6,657.0 \mathrm{a}(1,318.9 ; 24)$ \\
\hline Chopping of fresh forage & $2,125.9 \mathrm{a}(53,030 ; 23)$ & $46,300 \mathrm{~b}(11,250 ; 21)$ \\
\hline Feeding of animals ${ }^{5}$ & $9,457.4 \mathrm{a}(1,889.5 ; 19)$ & $2,727.6 \mathrm{~b}(82,020 ; 22)$ \\
\hline Milk preparing & $1,129.3 \mathrm{a}(83,590 ; 9)$ & $79,320 \mathrm{a}(48,500 ; 19)$ \\
\hline Milk transportation & $1,942.6 b(32,370 ; 3)$ & $2,785.2 \mathrm{a}(25,620 ; 3)$ \\
\hline Forage harvesting & $7,475.3 \mathrm{a}(2,378.4 ; 18)$ & $1,839.1 \mathrm{~b}(33,210 ; 19)$ \\
\hline Removing goat manure 6 & $2,784.4 \mathrm{a}(55,300 ; 3)$ & $2,802.0 \mathrm{a}(67,400 ; 3)$ \\
\hline
\end{tabular}

${ }^{1}$ Efficiency coefficients in total days $\times$ man worked per litre of milk produced $(\mathrm{dm} / \mathrm{L})$.

${ }_{2}^{2}$ Means followed by different superscripts on the same row differ $(\mathrm{P}<0.10)$.

${ }_{3}^{3}$ Means and standard deviations must be multiplied by for scale appropriateness.

4 The cleaning of the slatted floors and corridors of stilted-type barns were included on this item.

5 The task of cleaning troughs was added to this activity.

${ }^{6}$ Including manure distribution over forage fields.

activity. Although the eldest son took the lowest part by accomplishing daily work with goats (1\%), his work with the dairy cattle activity was essential. The sons also performed their scholar obligations and the wife, besides feeding, milking and taking care of animals (30\%), also kept the housework. The owner was responsible for the business management and the family dedicated five hours and 55 minutes of work per day on goats.

The annual income observed for farm A was obtained from selling milk to the association $(83.22 \%)$, animals $(6.54 \%)$ and from a positive capital stock variation (10.24\%). These components contributed with $92.80,3.36$ and $3.84 \%$ of farm 
B income, which demonstrated the dairy specialization of both farms (Table 3). The price paid by the association to farm unit B per litre of milk was the same paid to A, that is, approximately $\mathrm{R} \$ 0.95$. Nevertheless, an average value per litre of milk earned by farmer B was close to $\mathrm{R} \$ 1.04$, because $14.61 \%$ of produced milk was sold locally at an unitary price of $\mathrm{R} \$ 1.50$. It is important to point out that home consumption of goat milkwas negligible in both cases.

Two differences between technical efficiency coefficients of each goat farm pointed out to EOC: wages and amount of concentrate spent per litre of milk produced (Table 3). Although milk transportation cost was null in unit B, indirect costs were computed in TOC by means of cart and horse depreciation, and time spent by family members to transport milk to the receiving station. The difference between energy consumption occurred due to its strict use as motive power in unit A. Diesel oil was used for this sense in unit B and electricity was consumed to store milk in a freezer until its transportation to the city. The latter also occurred in unit A. Goat manure did not provide net financial results, once it was consumed as an organic fertilizer in both farm units.

After interviews, was observed that farmers usually notice only short-term costs components. In this sense, goat

Table 3 - Results from the enterprise budget analysis on both dairy goat households 1,2

\begin{tabular}{|c|c|c|c|}
\hline Item & Unit & Farm A & Farm B \\
\hline \multicolumn{4}{|l|}{ 1. Total receipts (TR) } \\
\hline Milk & $\mathrm{R} \$ / \mathrm{L}$ & 0.95360 & 1.03864 \\
\hline Animals & $\mathrm{R} \$ / \mathrm{L}$ & 0.07494 & 0.03799 \\
\hline Capital stock variation & $\mathrm{R} \$ / \mathrm{L}$ & 0.11729 & 0.04240 \\
\hline \multicolumn{4}{|l|}{ 2. Effective operating cost (EOC) } \\
\hline Salaried labour ${ }^{3}$ & $\mathrm{dm} / \mathrm{L}$ & 0.03108 & zero \\
\hline Concentrate ${ }^{4}$ & $\mathrm{~kg} / \mathrm{L}$ & 0.60291 & 0.27871 \\
\hline Goat milk replacer $^{5}$ & $\mathrm{~L} / \mathrm{L}$ & 0.02488 & 0.03578 \\
\hline Minerals ${ }^{6}$ & $\mathrm{~kg} / \mathrm{L}$ & 0.01064 & 0.00670 \\
\hline Milk transportation & $\mathrm{R} \$ / \mathrm{L}$ & 0.03016 & zero \\
\hline Energy $^{7}$ & $\mathrm{kWh} / \mathrm{L}$ & 0.18019 & 0.05802 \\
\hline Fuel (diesel oil $)^{8}$ & $\mathrm{~L} / \mathrm{L}$ & zero & 0.00241 \\
\hline Repairs and maintenance & $\mathrm{R} \$ / \mathrm{L}$ & zero & 0.00737 \\
\hline Medicines & $\mathrm{R} \$ / \mathrm{L}$ & 0.01170 & 0.00124 \\
\hline Other variable costs & $\mathrm{R} \$ / \mathrm{L}$ & 0.00695 & zero \\
\hline \multicolumn{4}{|l|}{ 3. Total operating cost (TOC) } \\
\hline EOC & $\mathrm{R} \$ / \mathrm{L}$ & 0.86182 & 0.21083 \\
\hline Family labour $^{3}$ & $\mathrm{dm} / \mathrm{L}$ & 0.03108 & 0.01807 \\
\hline Management by family ${ }^{3}$ & $\mathrm{dmm} / \mathrm{L}$ & 0.00770 & 0.00620 \\
\hline \multicolumn{4}{|l|}{ Depreciation } \\
\hline Building & $\mathrm{R} \$ / \mathrm{L}$ & 0.01993 & 0.01103 \\
\hline Equipment & $\mathrm{R} \$ / \mathrm{L}$ & 0.00766 & 0.01044 \\
\hline Service animals & $\mathrm{R} \$ / \mathrm{L}$ & 0.00766 & 0.00603 \\
\hline \multicolumn{4}{|l|}{ 4. Total cost (TC) } \\
\hline TOC & $\mathrm{R} \$ / \mathrm{L}$ & 1.57401 & 0.74714 \\
\hline Interest on operating capital ${ }^{9}$ & $\mathrm{R} \$ / \mathrm{L}$ & 0.02585 & 0.00632 \\
\hline \multicolumn{4}{|l|}{ Interest on investment ${ }^{9}$} \\
\hline Building & $\mathrm{R} \$ / \mathrm{L}$ & 0.03653 & 0.00607 \\
\hline Equipment & $\mathrm{R} \$ / \mathrm{L}$ & 0.00281 & 0.00566 \\
\hline Animals & $\mathrm{R} \$ / \mathrm{L}$ & 0.04441 & 0.02860 \\
\hline Land use opportunity cost & $\mathrm{R} \$ / \mathrm{L}$ & 0.01101 & 0.00169 \\
\hline $\mathrm{TC}$ & $\mathrm{R} \$ / \mathrm{L}$ & 1.69463 & 0.79548 \\
\hline 5. Cost of milk production & $\mathrm{R} \$ / \mathrm{L}$ & 1.50239 & 0.71509 \\
\hline \multicolumn{4}{|l|}{ 6. Returns } \\
\hline Gross margin (TR - EOC) & $\mathrm{R} \$ / \mathrm{L}$ & 0.28400 & 0.90820 \\
\hline Net income (TR - TOC) & $\mathrm{R} \$ / \mathrm{L}$ & -0.42819 & 0.37189 \\
\hline Profit (TR - TC) & $\mathrm{R} \$ / \mathrm{L}$ & -0.54881 & 0.32355 \\
\hline Rate of return (excluding land price) & $\% /$ year & -29.00 & 40.35 \\
\hline Rate of return (including land price ${ }^{10}$ ) & $\% /$ year & -25.81 & 42.38 \\
\hline \multicolumn{4}{|c|}{$1 \quad$ Brazilian currency $(\mathrm{R} \$ 1.00=$ US $\$ 0.34$ on August, 2004, and US $\$ 0.42$ on June, 2005$)$} \\
\hline \multicolumn{3}{|c|}{2 Amount of expended factor to total milk produced on a year-round basis. } & \\
\hline $3 \mathrm{dm}($ day $\times$ man equivalent $) \cong \mathrm{R} \$ 12.45$, and $\mathrm{dr}$ & $0.25 \times 3 \times \mathrm{dm}$ & & \\
\hline \multicolumn{4}{|c|}{4 Average cost in the period $(\mathrm{R} \$ / \mathrm{kg}) \cong 0.59($ farm $\mathrm{A})$ and 0.55 (farm $\mathrm{B})$. } \\
\hline \multicolumn{4}{|c|}{ 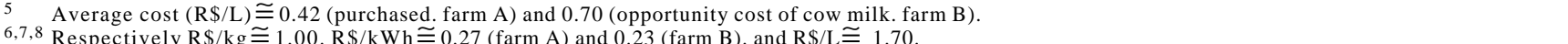 } \\
\hline $6,7,8$ Respectively $\mathrm{R} \$ / \mathrm{kg} \cong 1.00 . \mathrm{R} \$ / \mathrm{kWh} \cong 0.27$ & $\mathrm{R} \$ / \mathrm{L} \cong 1.70$ & & \\
\hline
\end{tabular}


farmers believed that their activities operated profitably, as a result of the positive gross margins settled at the end of the studied period (Table 3 ). The association received $\mathrm{R} \$ 1.06$ per litre of milk on average during 2004/2005, and charged an administration tax of $10 \%$. It should be emphasised that the industry, until then, did not employ differential prices according to milk volume supplied. On this situation, the milk value received by farmer B did not pay off the total costs other than EOC, which resulted on a loss account of almost $\mathrm{R} \$ 0.55 / \mathrm{L}$ of produced milk.

The opportunity cost of family labour does not appear to determine the household farmers' interest in goat production in several countries, once the economical feasibility of this business can be compromised by the inclusion of this item in the budget analysis. If the cost of family labour is neglected, the goat production generally shows a positive gross margin (Teufel et al., 1998; Hamadeh et al., 2001). Since family of unit A did not depend on farm income, the business endurance might become financially feasible, if corrective actions seeking an improvement on technical efficiency and herd indexes are implemented.

The situation in unit B was favourable, but in this case, the household income depended exclusively on economical performances of the activities developed at the farm. The dairy goat production was so profitable that enabled the family to pay off not only EOC, but also other production costs and interest upon fixed and circulating capital (Table 3). Even if the owner did not sell part of milk production locally, he would earn an approximate profit of $\mathrm{R} \$ 0.31 / \mathrm{L}$. The activity paid off the labour spent by the family an equivalent of R $\$ 0.51 / \mathrm{L}$.

Farm unit A spent 2.16 times more concentrate to produce the same amount of milk as unit B (Table 3). The highest positive stock mass variation implied greater concentrate needs by herd A, but that difference would not only explain the expense. The basic difference between herd diets was the forage used: napier grass vs. angola grass. These $\mathrm{C} 4$ grasses (particularly the former) presents high yield in tropical conditions that could be enhanced by fertilization. During vigorous growth, these species produce large amounts of lignified cell wall while vegetative growth persists (Van Soest, 1994). For instance, this process causes a linear increase on the filling effect of the elephant grass fibrous matter (Vieira et al., 1997), which brings constraints for high producing animals that need lower retention times of the rumen digesta (Demment and Longhurst, 1987; Van Soest, 1987). The animal size is an additional limitation to the digesta dynamics and fill is pronounced when small ruminants are fed with diets rich in insoluble fibre. The forage chopping restrains the selection but goats are still capable of selecting fragments of higher quality and in case of upright growing, forage plants such as elephant grass, as much as $60 \%$ of forage fed could be refused, what jeopardise intake and performance (Demment and Longhurst, 1987; Van Soest, 1987; Fedele et al., 2002). Napier grass was harvested at $150 \mathrm{~cm}$ high in unit $\mathrm{A}$, on average, whereas only non senescent vegetative parts of angola grass were harvested to be offered to goats in farm B. If the performance of productive functions depends on the quality of forage, then, the degradation and passage kinetic properties of angola grass rendered more nutrients to dairy goats than napier grass. Nevertheless, this hypothesis must be confirmed after future research.

Results from the budget analysis performed in unit B were considered to assess the business viability and for applying sensitivity tests. The annual cash flows simulated $\left(\mathrm{C}_{2}\right.$ to $\left.\mathrm{C}_{5}\right)$ from current results $\left(\mathrm{C}_{0,1}\right)$ amounted to $0.39940 \mathrm{R} \$ \mathrm{~L}$. Investments $\left(\mathrm{C}_{0}\right)$ in animals, building, equipment and land scored $0.80183 \mathrm{R} \$ / \mathrm{L}$. Thus, a resultant NPV of $1.38825 \mathrm{R} \$ / \mathrm{L}$ was estimated, with a business irr of $48.62 \%$. This profitability is considered high for livestock production, particularly if production factors including depreciation, interest in capital and family labour for work and management are considered. The system would be feasible even in a pessimist scene, as revealed by the application of sensitivity tests, because a positive NPV of $0.96046 \mathrm{R} \$ / \mathrm{L}$ and an irr of $39.30 \%$ have demonstrated the feasibility and robustness of the dairy goat husbandry when performed according to the household production model.

The farm B owner family depended strictly on activities performed to earn necessary income to satisfy their needs, whereas farm A owner family should only bring balance to the cash flows. When the family does not have other sources, the family income may be in jeopardy if a loss account perspective dominates in the long term. Income dependence on farm activities could explain differences between profitable systems from those presenting deficiency (Teufel et al., 1998; Sinn et al., 1999). Therefore, unit B had to be more efficient in several aspects (Tables 2 and 3 ) and the household model allowed a natural optimisation of the production factors (Zaibet et al., 2004).

Milk produced at an approximate cost of US\$ $0.27 / \mathrm{L}$ (Table 3) may be considered competitive when compared to prices reported by Dubeuf et al. (2004) in Spain (US\$0.43/L), Italy (US\$ 0.46/L), Greece (US\$ 0.56/L) and France (US\$ 0.49/L). In these countries, the ratio between gross margin (US\$) to the yearly worked hours on the activity (worker units, WU) resulted in 18,148.00, 25,926.00, 14,259.00 and 20,740.00 US\$/WU (Rancourt et al., 2006). The estimated efficiencies related to farms A and B were 
4,226.29 and 7,585.63 US\$/WU, by considering 242 days $\times$ man worked per year.

Income earned on B corresponded to family labour remuneration raised by profit which rendered $\mathrm{R} \$ 9,772.86 /$ year. This amounted to a monthly salary of $\mathrm{R} \$ 732.96$ (US\$ 278.52) including $13^{\text {th }}$ salary and an additional $1 / 3$ salary due to vacation, with the advantage of being the business owner. The Brazilian minimum monthly wage at that time was R $\$ 300.00$ (US\$114.00). If the owner couple would have to work outside their farm to earn equivalently, the income would be lower, i.e., R\$ 600.00 (US\$228.00). Nevertheless, the entire family worked with dairy goats and spent 42 hours a week. If only the couple would have to work outside, a weekly journey of 88 hours should be accomplished. It deserves to be mentioned that the goat production on unit B provided $50 \%$ of the family income, which was complemented by the dairy cattle results.

It is believed that goat milk production according to a household model does not need large quantities of production factors (land, building), occupies family members and represents a viable alternative for gender equity on the rural sector (Johnson et al., 1986; Sinn et al., 1999). The results observed in the present study corroborate such hypothesis.

Petroleum exploitation had thrust the Fluminense economy and several economic sectors increased labour demand in cities such as Macaé, Campos dos Goytacazes and those of the metropolitan region. These medium and large cities still strongly attract hand labour from all northwestern State counties. However, as Abramovay (2000) emphasised, the opportunity cost of such provincial hand labour is low due to the low schooling. Under these circumstances, earnings with efficient goat milk production (gross margin/WU) could counteract the dazzling of the cities. Recently, after contacting farmer from unit B, was verified that he acquired and incorporated with its own funds, 7.3 ha to his property, with the goal of enlarging the dairy goat system so that the eldest son could succeed him. It is worth to emphasise that this farmer used only public school and health services and has never been a beneficiary of any governmental assistance program nor subsides. The success of the family business succession is a challenge for attaining sustainable development. Enough land assurance for young farmers and compatible financing is essential to maintain families on rural areas, proud of their business and rural life (Morand-Fehr and Boyazoglu, 1999; Silvestro et al., 2001; Haenlein, 2001). The dairy goat system profitability demonstrated in the household agriculture model could guarantee an opportunity for young farmers to succeed their parents' business. Perhaps profit and full remuneration of family labour turn them less susceptible to social-economic pressures and avoid their migration to the cities, where an equal quality of life and expectations about the future are rather uncertain.

\section{Conclusions}

Goat dairying is an activity that can generate income and wealth for rural farmers. It makes possible the fulfilling of family needs in every way, and the activity has enabled them to reinvest earnings on their production factors. The development of this activity in the household agriculture makes possible the effectiveness of women in the rural business, which increases gender equity in a typically masculine environment. The work in this activity can occupy the whole family and the economical performance of goat dairying turns smallholdings viable, given that enterprises are inserted into the productive chain and there are no restrictions upon the commercialization of its main product, i. e. in natura milk, particularly because it represents more than $85 \%$ of the activity income. Another point of relevance is the fact that the activity can produce enough wealth for the succession of the business employed by the family, which is an important instrument of jobs and income generation, and development of the rural environment.

\section{Acknowledgements}

The authors gratefully acknowledge the assistance of EMATER-RIO in the person of Denilson Bazeth, and we are deeply indebted to Mr. Antônio Carlos and Mr. Mauro Prevatto and their respective families for their warm welcome, what made possible the present work. And finally we wish to thank CNPq, CAPES, FAPERJ and UENF for grants.

\section{Literature Cited}

ABRAMOVAY, R. Agricultura familiar y desarrollo territorial (Household agriculture and regional development). Revista da Associação Brasileira de Reforma Agrária, n.28, p.1-21, 1999.

AGRICULTURAL AND FOOD RESEARCH COUNCIL - AFRC. The nutrition of goats. Walingford: CAB International, Nutrition Abstracts and Reviews Series B, v.67, n.11, 1997. 830p.

BOYAZOGLU, J.; MORAND-FEHR, P. Systems of goat production and the evironment. In: INTERNATIONAL CONFERENCE ON GOATS, 4., 1987, Brasília. Anais... Brasília: IGA/ EMBRAPA, 1987. p.95.

CASTRO, C.P. Processing of goats milk under less favorable conditions in small rural familiar agroindustry: present situation and perspectives. In: INTERNATIONAL CONFERENCE ON GOATS, 4., 1987, Brasília. Anais... Brasília: IGA/EMBRAPA, 1987. p. 283

CENTRO DE INFORMAÇÕES E DADOS DO RIO DE JANEIRO CIDE. Anuário Estatístico do Estado do Rio de Janeiro 
(Statistical Yearbook of the State of Rio de Janeiro). Rio de Janeiro, 1998. 433p.

CORDEIRO, P.R.C. Produção de leite de cabra no Brasil (Goat milk production in Brazil). In: MATTOS, W.R.S. (Ed). A produção animal na visão dos brasileiros. Piracicaba: Sociedade Brasileira de Zootecnia, 2001. p.497-503.

DEMMENT, M.W.; LONGRURST, W.M. Browsers and grazers: constraints on feeding ecology imposed by gut morphology and body size. In: INTERNATIONAL CONFERENCE ON GOATS. 4., 1987, Brasília. Anais... Brasília: IGA/EMBRAPA, 1987. p.989.

DUBEUF, J.P.; MORAND-FEHR, P.; RUBINO, R. Situation, changes and future of goat industry around the world. Small Ruminant Research, v.51, n.2, p.165-173, 2004.

FEDELE, V.; CLAPS, S.; RUBINO, R. et al. Effect of free-choice and traditional feeding systems on goat feeding behaviour and intake. Livestock Production Science, v.74, p.19-31, 2002.

GOMES, S.T.; SANTOS, P.C.B. Custo de produção de leite de cabra. Agropecuária Fluminense: EMATER-RIO, 1995. 32p.

GUIMARÃES, V.P. Curva de lactação, efeitos ambientais e genéticos sobre o desempenho produtivo de cabras leiteiras. 2004. 87f. Dissertação (Mestrado em Zootecnia) Universidade Federal de Viçosa, Viçosa, MG, 2004.

HAENLEIN, G.F.W. Past, present, and future perspectives of small ruminant dairy research. Journal of Dairy Science, v.84, p.2097-2115, 2001.

HAMADEH, S.K.; BISTANJI, G.N.; DARWISH, M.R. et al. Economic sustainability of small ruminants production in semiarid areas of Lebanon. Small Ruminant Research, v.40, n.1, p.41-49, 2001.

INSTITUTO BRASILEIRO DE GEOGRAFIA E ESTATÍSTICA IBGE. Anuário Estatístico do Brasil (Brazilian Statistical Yearbook). Rio de Janeiro: 1976. 813p.

INSTITUTO BRASILEIRO DE GEOGRAFIA E ESTATÍSTICA IBGE [2006]. Disponível em: <http://www.ibge.gov.br> Acesso em: $15 / 12 / 2006$.

JOHNSON, W.L.; VAN EYS, J.E.; FITZHUGH, H.A. Sheep and goats in tropical and subtropical agricultural systems. Journal of Animal Science, v.63, p.1587-1599, 1986.

KNIGHTS, M.; GARCIA, G.W. The status and characteristics of the goat (Capra hircus) and its potential role as a significant milk producer in the tropics: a review. Small Ruminant Research, v.26, p.203-215, 1997.

LUO, J.; GOETSCH, A.L.; SAHLU, T. et al. Prediction of metabolizable energy requirements for maintenance and gain of preweaning, growing and mature goats. Small Ruminant Research, v.53, p.231-252, 2004.
MORAND-FEHR, P.; BOYAZOGLU, J. Present state and future outlook of the small ruminant sector. Small Ruminant Research, v.34, p.175-188, 1999.

MORAND-FEHR, P.; BOUTONNET, J.P.; DEVENDRA, C. et al Strategy for goat farming in the $21^{\text {st }}$ century. Small Ruminant Research, v.51, p.175-183, 2004.

NSAHLAI, I.V.; GOETSCH, A.L.; LUO, J. et al. Metabolizable energy requirements of lactating goats. Small Ruminant Research, v.53, p.253-273, 2004.

PROGRAMA DAS NAÇÕES UNIDAS PARA O DESENVOLVIMENTO - PNUD, [2006]. Atlas do Desenvolvimento Humano no Brasil (Atlas of the Human Development in Brazil). Disponível em: <http:// www.pnud.org.br> Acesso em: 15/12/2006.

RANCOURT, M.; FOIS, N.; LAVÍN, M.P. et al. Mediterranean sheep and goat production: an uncertain future. Small Ruminant Research, v.62, p.167-179, 2006

SAHLU, T.; GOETSCH, A.L.; LUO, J. et al. Nutrient requirements of goats: developed equations, other considerations and future research to improve them. Small Ruminant Research, v.53, p.191-219, 2004.

SILVA, R.R. Agribusiness da caprinocultura de leite no Brasil Salvador: Bureau, 1998. 74p.

SILVESTRO, M.L.; ABRAMOVAY, R.; MELlO, M.A. et al. Os impasses da sucessão hereditária na agricultura familiar. Florianópolis: EPAGRI and Ministério do Desenvolvimento Agrário, 2001. 120p.

SINN, R.; KETZIS, J.; CHEN, T. The role of woman in the sheep and goat sector. Small Ruminant Research, v.34, p.159-269, 1999.

TEUFEL, N.; KUETTNER, K.; GALL, C. Contribution of goat husbandry to household income in the Punjab (Pakistan): a review. Small Ruminant Research, v.28, p.101-107, 1998.

Van SOEST, P.J. Interactions of feeding behavior and forage composition. In: INTERNATIONAL CONFERENCE ON GOATS. 4., 1987, Brasília. Anais... Brasília: IGA/EMBRAPA, 1987. p.971.

Van SOEST, P.J. Nutritional ecology of the ruminant. Ithaca:Cornell University Press, 1994. 476p.

VIEIRA, R.A.M.; PEREIRA, J.C.; MALAFAIA, P.A.M. et al. The influence of elephant grass (Pennisetum purpureum Schum. Mineiro variety) growth on the nutrient kinetics in the rumen. Animal Feed Science Technology, v.67, p.151-161, 1997.

ZAIBET, L.; DHARMAPALA, P.S.; HOUGHANMI, H. et al. Social changes, economic performance and development: the case of goat production in Oman. Small Ruminant Research, v.54, p.131-140, 2004. 